Disclosure of Interests: Denis Poddubnyy Grant/research support from: AbbVie, MSD, Novartis, and Pfizer, Consultant of: AbbVie, Bristol-Myers Squibb, Eli Lilly, MSD, Novartis, Pfizer, Roche, UCB, Speakers bureau: AbbVie, Bristol-Myers Squibb, Eli Lilly, MSD, Novartis, Pfizer, Roche, UCB, Effie Pournara Shareholder of: Novartis, Employee of: Novartis, Agnieszka Zielińska Consultant of: Novartis, Pfizer, Asta Baranauskaite Consultant of: AbbVie, Speakers bureau: Novartis, AbbVie, Amgen, Roche, KRKA, Alejandro Muñoz Jimenez.: None declared, Preeti Kumari Employee of: Novartis Healthcare Pvt. Ltd., Barbara Schulz Employee of: Novartis, Michael Rissler Shareholder of: Novartis, Employee of: Novartis, Chiara Perella Shareholder of: Novartis, Employee of: Novartis, Helena Marzo-Ortega Grant/research support from: Janssen, Novartis, Consultant of: Abbvie, Celgene, Eli Lilly, Janssen, Novartis, Pfizer, UCB, Speakers bureau: Abbvie, Celgene, Eli Lilly, Janssen, Novartis, Pfizer, Takeda, UCB

DOI: 10.1136/annrheumdis-2020-eular.299

\begin{tabular}{|l|l}
\hline AB0660 & LONG-TERM CLINICAL OUTCOME OF ANTI-TNF \\
TREATMENT IN PATIENTS WITH EARLY AXIAL \\
SPONDYLOARTHRITIS: 10-YEAR DATA OF THE \\
ETANERCEPT VS. SULFASALAZIN IN EARLY AXIAL \\
SPONDYLOARTHRITIS TRIAL
\end{tabular}

F. Proft $^{1}$, M. Torgutalp ${ }^{1}$, A. Weiß ${ }^{2}$, M. Protopopov ${ }^{1}$, V. Rios Rodriguez ${ }^{1}$, H. Haibel ${ }^{1}$, O. Behmer ${ }^{3}$, J. Sieper ${ }^{1}$, D. Poddubnyy ${ }^{1,2} .{ }^{1}$ Charité $^{2}$

Universitätsmedizin Berlin, Berlin, Germany, Berlin, Germany; ${ }^{2}$ German

Rheumatism Research Centre, Berlin, Germany; ${ }^{3}$ Pfizer Pharma GmbH, Berlin, Germany

Background: Long-term data on anti-TNF treatment in patients with early axial spondyloarthritis $(\mathrm{SpA})$ is scarce.

Objectives: The objective of this analysis was to assess the long-term clinical efficacy (up to 10 years of treatment) of a tumor necrosis factor (TNF) inhibitor etanercept (ETN) in patients with early axial spondyloarthritis, who participated in the long-term (until year 10) extension of the ESTHER (Etanercept vs. Sulfasalazine in Early Axial Spondyloarthritis Trial) trial.

Methods: In the previously reported ESTHER trial, patients with early active axial SpA [including both non-radiographic axial $\mathrm{SpA}(\mathrm{nr}-\mathrm{axSpA})$ and radiographic axial SpA (r-axSpA)/ankylosing spondylitis (AS)] with a symptom duration of $<5$ years and a positive MRI of the sacroiliac joints (SIJs) and/or the spine at baseline) were treated with ETN $(n=40)$ or sulfasalazine (SSZ) $(n=36)$ during the first year (1). At year 1, all patients who were not in remission continued with - or switched (in case of SSZ therapy) to - ETN for up to 10 years in total (1). Patients in remission discontinued their therapy and were followed-up until end of year 2; in case of remission loss, ETN was (re)-introduced and continued till the end of year 10 .

Figure 1: Observed response rates to etanercept $(A)$ and the course of disease related parameters in study completers $(n=19)(B)$.
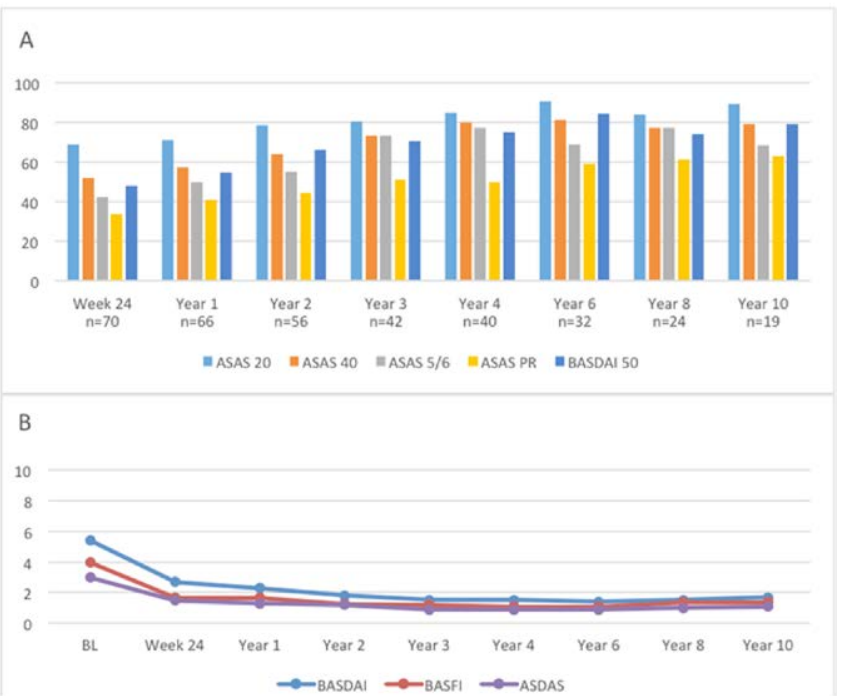

Table 1. Baseline characteristics of patients with axial spondyloarthritis who completed the study as compared to patients who dropped out.

\begin{tabular}{lccc}
\hline & $\begin{array}{c}\text { Completer } \\
(\mathbf{n}=\mathbf{1 9})\end{array}$ & $\begin{array}{c}\text { Non-Completer } \\
(\mathbf{n}=57)\end{array}$ & p value \\
\hline Age, years & $32.5(7.4)$ & $32.8(8.9)$ & 0.91 \\
Male patients, $\mathrm{n}(\%)$ & $15(78.9)$ & $29(50.9)$ & $\mathbf{0 . 0 3 4}$ \\
Symptomduration, years & $1.1(1.2)$ & $1(1.7)$ & 0.81 \\
HLA-B27 positivity, $\mathrm{n}(\%)$ & $18(94.7)$ & $44(77.2)$ & 0.091 \\
Elevated CRP (CRP>5mg/l), $\mathrm{n}(\%)$ & $7(38.9)$ & $33(62.3)$ & 0.088 \\
Fulfilled New York criteria, $\mathrm{n}(\%)$ & $12(63.2)$ & $27(47.4)$ & 0.24 \\
Patient global (0-10) & $6.1(1.9)$ & $7.2(1.7)$ & $\mathbf{0 . 0 2 5}$ \\
Physician global (0-10) & $5.5(1.5)$ & $6.5(1.2)$ & $\mathbf{0 . 0 0 7}$ \\
ASDAS & $3(0.7)$ & $3.5(0.8)$ & $\mathbf{0 . 0 4 2}$ \\
BASDAI (0-10) & $5.4(1.1)$ & $5.8(1.3)$ & 0.27 \\
BASFI (0-10) & $4(2.1)$ & $4.4(2)$ & 0.41 \\
BASMI (0-10) & $1.2(1.3)$ & $2(1.6)$ & $\mathbf{0 . 0 3 9}$ \\
AS-QoL (0-18) & $7.6(3.9)$ & $10.1(3.9)$ & $\mathbf{0 . 0 1 9}$ \\
\hline
\end{tabular}

Results: Out of 76 initial patients, $25 \%(n=19,12$ with $r$-axSpA and 7 with nr-axSpA) completed year 10 of the study. At baseline, completers were significantly more often male and showed lower values of patient (PGA) and physician global assessments of disease activity (PhGA), ASDAS (Ankylosing Spondylitis Disease Activity Score), BASMI (Bath Ankylosing Spondylitis Metrology Index), and AS-QoL (Ankylosing Spondylitis Quality of Life Questionnaire) as compared to non-completers (Table 1). When analyzing clinical data of the completers, mean BASDAI, BASFI and ASDAS values were constantly $<2$ during the follow up with no statistically significant differences between the r-axSpA and nr-axSpA sub-groups (Table 2, Figure $1 B)$. In the entire group, a sustained clinical response was observed over 10 years of follow up (Figure 1A). A total of 39 serious adverse events were documented over the 10 years of the study, while six of them were seen as possibly associated with ETN treatment, which lead in five patients (one lymphoma, one sarcoidosis, one demyelinating neurological disease, one elevated liver enzymes and one recurrent minor infections) to an ETN discontinuation.

Conclusion: A sustained clinical response was shown over the 10 years of the study for the completers with comparable rates between r-axSpA and nr-axSpA. ETN was well tolerated across the entire treatment period and showed a good safety profile with no new safety signals.

Acknowledgments: The ESTHER study was supported by an unrestricted research grant from Pfizer.

Murat Torgutalp's work at Charité was supported by an award from the Scientific and Technological Research Council of Turkey.

Disclosure of Interests: Fabian Proft Grant/research support from: Novartis Pharma GmbH, Consultant of: Consultancy / speaker fees from: Abbvie, BMS, Celgene, Lilly, MSD, Novartis, Pfizer, Roche, UCB, Speakers bureau: Consultancy / speaker fees from: Abbvie, BMS, Celgene, Lilly, MSD, Novartis, Pfizer, Roche, UCB, Murat Torgutalp: None declared, Anja Weiß: None declared, Mikhail Protopopov Consultant of: Novartis, Valeria Rios Rodriguez Consultant of: Abbvie, Novartis, Hildrun Haibel Consultant of: Abbvie, Jansen, MSD, and Novartis, Speakers bureau: Abbvie, Jansen, MSD, and Novartis, Olaf Behmer Employee of: Pfizer Pharma GmbH, Joachim Sieper Consultant of: AbbVie, Boehringer Ingelheim, Eli Lilly and Company, Janssen, Merck, Novartis, Pfizer, Roche, and UCB Pharma, Speakers bureau: AbbVie, Boehringer Ingelheim, Eli Lilly and Company, Janssen, Merck, Novartis, Pfizer, Roche, and UCB Pharma, Denis Poddubnyy Grant/research support from: AbbVie, MSD, Novartis, and Pfizer, Consultant of: AbbVie, Bristol-Myers Squibb, Eli Lilly, MSD, Novartis, Pfizer, Roche, UCB, Speakers bureau: AbbVie, Bristol-Myers Squibb, Eli Lilly, MSD, Novartis, Pfizer, Roche, UCB

DOI: 10.1136/annrheumdis-2020-eular.3136

\section{AB0661 CO-MEDICATIONS MAY ALTER THE RESPONSE TO TNF-INHIBITORS IN SPONDYLOARTHRITIS PATIENTS:} A PHARMACOMICROBIOMIC EFFECT?

M. Masson ${ }^{1}$, M. Kostine ${ }^{1}$, T. Barnetche ${ }^{1}$, M. E. Truchetet ${ }^{1}$, C. Richez ${ }^{1}$,

T. Schaeverbeke ${ }^{1} .{ }^{1}$ Bordeaux Universitary Hospital, Bordeaux, France

Background: The reason why some spondyloarthritis (SA) patients fail to respond to TNF inhibitors (TNF-i) remains unclear. Recently, it has been shown in 